\title{
Spelling Worktext and Performance of Grade 11 Students of Esperanza National High School
}

DOI: https://doi.org/10.47175/rielsj.v2i3.296

\author{
| Imie M. Soquita, MAT
}

\author{
Esperanza National High \\ School, Poblacion, Esperanza, \\ Sultan Kudarat, Region XII, \\ Philippines
}

samsudinabdullah42@yahoo.com

\begin{abstract}
This study examined the level of achievement in Spelling of the Grade 11 students of Esperanza National High School and acceptability of the Rule-based Spelling Worktext Module in helping the students improve their spelling competencies. It employed experimental design and utilized 50 students to the control group and 50 students to compose the experimental group. For the experimental group, the researcher used the Rulebased Spelling Worktext while Copy-Only Method was applied to the control group. After allotted weeks for spelling instruction, a post- test was conducted to see if there are significant differences on the performance of students in spelling in control and experimental groups. To solve, analyze and interpret the result of the study, percentages, mean, and z-test were used. Study showed that the acceptability level of the Rule-based Spelling Worktext based on its content, relevance and instructional aspect were all described as "Excellent." The z-test results showed that the spelling performance of the students from the control and experimental groups was the same in pre-test but not significantly the same in post-test. This implied that the experimental group of students showed significant improvement in the post-test than in control group. This improvement in their performance in spelling could be credited to the Rule-based Spelling Worktext which was used with the experimental group in teaching spelling.
\end{abstract}

KEYWORDS

worktext; spelling; student; high school

\section{INTRODUCTION}

Spelling skills are something people are not inborn with. People learn to spell as they learn to read and write. Learning to spell words plays a vital role in improving child's future. The basic foundation that a child needs throughout his educational career is his spelling ability. A child's spelling ability is important as it supports him in reading. Spelling helps strengthen the link being shared by sounds and letters. It aids in reading and writing. That's why, students need to learn spelling words during their early stages of development. As a matter of fact, proficiency with language is the common factor of spelling and reading.

Spelling is applied to almost all aspects of life. The ability to write fluently is directly related to the ability to spell correctly. Reading and spelling abilities are also tied directly to each other. A child's ability to spell gives him a power to put his thoughts onto writing, and fully expresses himself with the current events. Spelling is the art of correct assembling of words from the letters. It is one of the essential components of successful writing. Being self-assured at spelling leads to confidence in all aspects of literacy. It has been proven that the ability to recognize the links between word of the same origin and understanding word relationships aids comprehension skills. 
Many authors stated that spelling is important in written communication. Lipura (2014) as cited from Moats (2000) told that correct spelling transports good communication between senders and receivers of the message. He said that wrong spelling allows communication misinterpreted. Words that are spelt wrongly can be misunderstood. Wrong spelling can confuse the readers to understand the message of the writers.

Teaching students the approaches and guidelines to develop their spelling and vocabulary skills gives them an opportunity to improve their everyday life. With the advent technology when texting becomes the common mode of communication, spelling has become a least prioritized skill to develop in English. As long as one can send the message across, a disregard to correct spelling becomes less embarrassing. This becomes a problem in the classroom when a student in senior high school is expected to be fluent not only in speaking but in writing as well. Spelling then should not be compromised with the millennial standard of spelling and writing.

Senior high school students of Esperanza National High School are not exempted to this kind of scenario. During the classroom spelling activities, students in Technical Vocational Livelihood (TVL) class found to have difficulty in spelling. These TVL students are students who prefer to manipulate objects and equipment than speak and write. Every time there are quizzes, term papers, reading reports, paragraphs, notes and assignments and even their answers in periodical exams contained misspelled words. Considering the value of spelling to their academic success, these students need to master the rules of spelling to avoid errors in written communication and engagements. Even if their work does not require most of the reading and writing, they cannot do without reading and writing in their lives.

Since spelling can lay the basic foundation a child needs in his education and life, the researcher conducts a research of the students' performance in spelling to help her gauge in making intervention material that will help improve their performance in spelling. The Rule-Based Spelling Worktext is thereby considered as an effective tool to help the students master the rules in spelling and eventually improve their spelling performance.

\section{Conceptual Framework}

The conceptual framework of the study is illustrated in Figure 1.

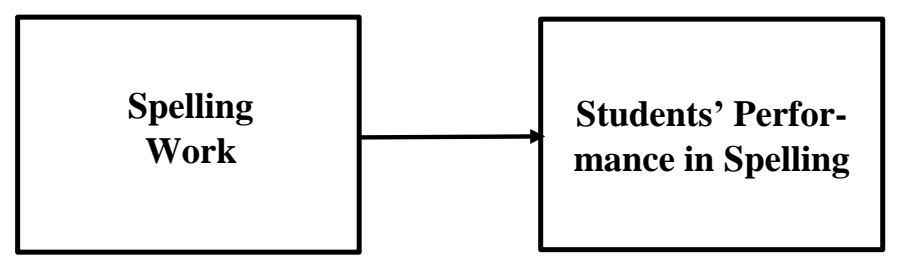

Figure 1. Research Paradigm

The Rule-based Spelling Strategy will be employed in the classroom to improve students' difficulty in spelling and help them achieve spelling fluency.

Tomlin (2005), as cited from Darch et al. (2000), stated that the best way to let students overcome their spelling difficulties is teaching them the rule-based spelling strategy. Rulebased strategy is letting the students to be familiar with forms and guidelines in merging letters to form words. People understandably communicate with each other through words.

It is believed that rule-based strategy in spelling to be employed in the classroom can enhance students' performance in spelling. 


\section{Statement of the Problem}

The study aimed to determine the level of spelling ability of the senior high school students in Technical Vocational Livelihood (TVL) class at Esperanza National High School.

Specifically, it attempted to answer the following questions, to wit:

1. What is the level of achievement in spelling of Grade 11 students in the control and experimental groups in the pre-test and post-test?

2. What is the level of acceptability of the Rule-based Spelling Worktext in terms of the following criteria, to wit:

2.1 Content;

2.2 Relevance; and

2.3 Instructional Aspect?

3. Is there a significant difference on the performance of students in spelling in the control and experimental group in the pre-test and post-test?

4. Is there a significant difference in the mean gain scores of students in spelling in the control and experimental group in post- test?

\section{RESEARCH METHODS}

\section{Research Design}

The study employed experimental design that applied pre-test and post-test to the control and experimental groups before and after the experimentation.

\section{Respondents of the Study}

The respondents of this study were the 100 randomly selected students from Grade 11Technical Vocational and Livelihood (TVL) classes of Esperanza National High School. The first 50 students comprised the control group while another 50 students comprised the experimental group. These two sections were heterogeneously grouped. There were 6 sections of the TVL and each section had 60-62 students in the class so the researcher randomly selected 50 students from the selected sections to come-up with the two (2) groups to compose the control and experimental groups by 50 students each class.

\section{Locale of the Study}

The study was conducted in Esperanza National High School in the Division of Sultan Kudarat. The school is located in the last municipality of Sultan Kudarat towards Maguindanao province. It is considered as the biggest and leading school in Sultan Kudarat in terms of its population and achievement.

Although many tribes go to this school to study, Ilonggo tribe comprises the biggest population among them. The school then serves as a melting pot of different cultures as different tribes of students get mixed inside the classroom.

\section{Sampling Technique}

The researcher made used of the two sections of the Senior High School TVL classes to comprise the control and experimental groups. The students from both sections were randomly selected from the Grade 11-TVL classes of Esperanza National High School.

The students of Esperanza National High School were heterogeneously grouped. They are enrolled on a "first come, first listed" basis. The fact that they were heterogeneously grouped, it was expected that the students in the TVL classes are having almost the same academic performance. The result of the standardized test prior to the experimentation proved that they were significantly the same in terms of their performance in spelling. 


\section{Statistical Treatment}

The study made use of frequency, percentage, mean, and z-test used in the statistical treatment of the study. To determine the significant difference between the pre-test and post-test results of the control and experimental groups, z-test was used. According to Hechanova and Hechanova (2012), when sample size is large ( $\mathrm{n}$ is greater than 30), z-test is to be used to determine if there is a significant difference in the means of the two groups.

To determine the performance of students in spelling in every competency and the acceptability level of the Rule-based Spelling Worktext, frequency, percentage, and mean were used. To determine the significant difference on the performance of students in spelling in pre-test and post-test in the control and experimental groups, z-test was used.

\section{RESULTS AND DISCUSSION}

\section{Performance in Spelling of Grade 11 Students}

Table 1. Level of Performance of Grade 11 Students in Control Group

in the Pre-test and Post-test $(\mathrm{n}=50)$

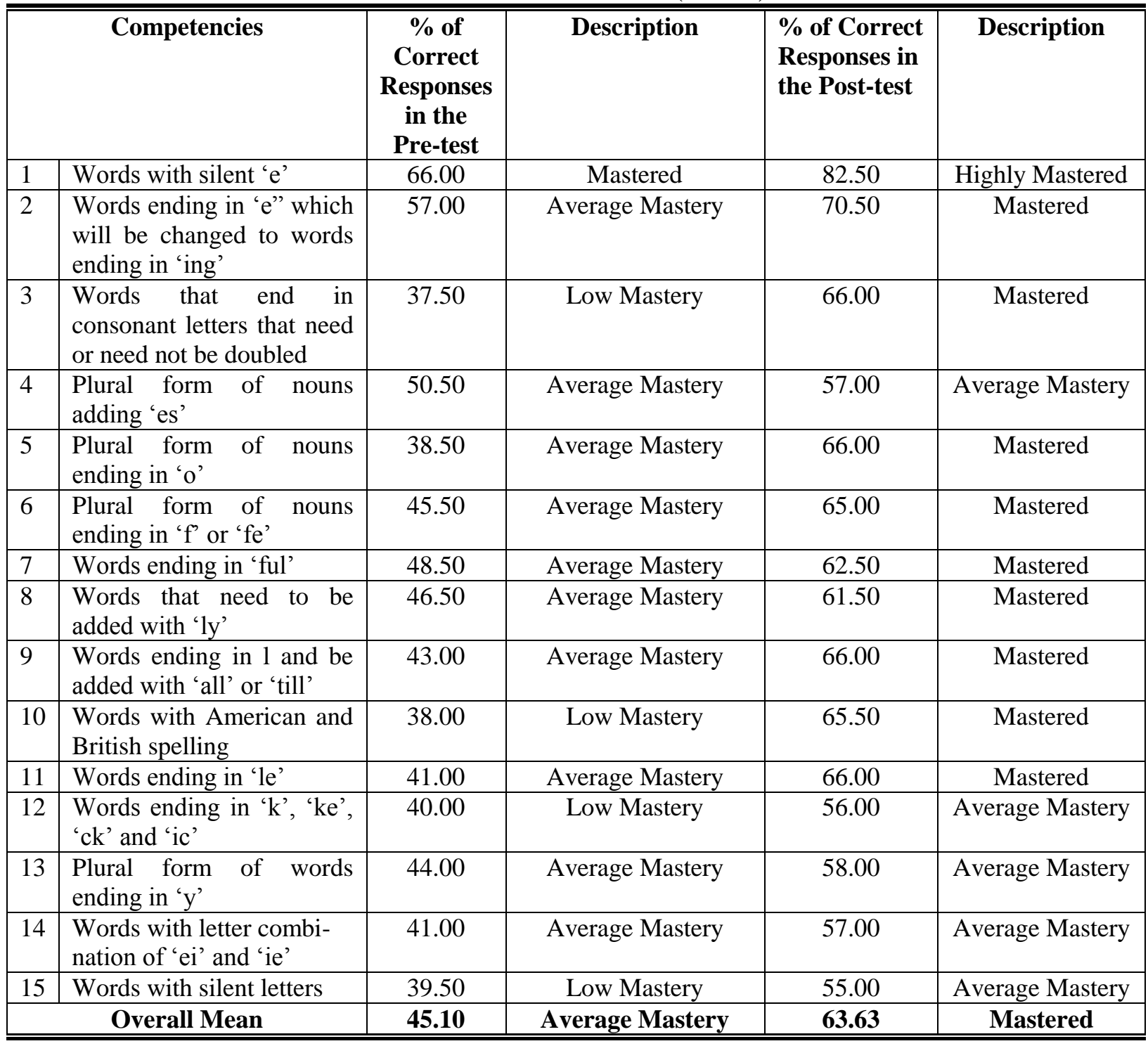

Table 1 presents the performance of students in spelling of the control group in pre-test and post-test. As shown, pre-test result showed that competency on "Words ending in 
consonant letters need or need not be doubled" got a mean of 37.50 percent of correct responses in pre-test and it is described as "Low Mastery." while "Words with silent "e"" got a mean of 66 percent of correct responses from the respondents and this is described as "Mastered".

However, post-test result showed that competency on "Words with silent letters" got the lowest mean which is 66 percent of correct responses while the competency on "Words with silent ' $\mathrm{e}$ "" got a mean of 82.50 percent correct responses which is the highest and it is described as "Highly Mastered."

As shown in the table, performance of students in spelling increased from pre-test to post test. The teacher employed the traditional way of teaching spelling in the control group like drills and pencil and paper test. Words are given at random but students can copy the correct spelling from the board and review at home.

The overall mean shows that the students' performance in spelling in pre-test is 45.10 which is described as "Average Mastery" while post test result is 63.63 and is described as "Mastered."

Johnson (2013) explained that the Copy-Only Method in teaching spelling can be one of the approaches to help students improve their competence in spelling, however, the gain and progress can only be minimal compared to the gain and progress they get using the Rule-Based instruction in spelling.

Table 2. Level of Performance of Grade 11 Students in Experimental Group in the Pre-test and Post-test $(\mathrm{n}=50)$

\begin{tabular}{|c|c|c|c|c|c|}
\hline \multicolumn{2}{|r|}{ Competencies } & \multirow{2}{*}{$\begin{array}{c}\begin{array}{c}\% \text { of Correct } \\
\text { Responses in } \\
\text { the Pre-test }\end{array} \\
67.50\end{array}$} & \multirow{2}{*}{$\begin{array}{c}\text { Description } \\
\text { Mastered } \\
\end{array}$} & \multirow{2}{*}{$\begin{array}{c}\begin{array}{l}\% \text { of Correct } \\
\text { Responses in } \\
\text { the Post-test }\end{array} \\
86.50\end{array}$} & \multirow{2}{*}{$\begin{array}{c}\text { Description } \\
\text { Highly Mastered }\end{array}$} \\
\hline 1 & Words with silent ' $\mathrm{e}$ ' & & & & \\
\hline 2 & $\begin{array}{l}\text { Words ending in "e" which } \\
\text { will be changed to words } \\
\text { ending in "ing' }\end{array}$ & 61.50 & $\begin{array}{l}\text { Average } \\
\text { Mastery }\end{array}$ & 82.00 & Highly Mastered \\
\hline 3 & $\begin{array}{l}\text { Words that end in } \\
\text { consonant letters that need } \\
\text { or need not be doubled }\end{array}$ & 38.50 & Low Mastery & 81.00 & Highly Mastered \\
\hline 4 & $\begin{array}{l}\text { Plural form of nouns } \\
\text { adding 'es' }\end{array}$ & 49.50 & Average Mastery & 83.00 & Highly Mastered \\
\hline 5 & $\begin{array}{l}\text { Plural form of nouns } \\
\text { ending in 'o' }\end{array}$ & 46.00 & Average Mastery & 81.00 & Highly Mastered \\
\hline 6 & $\begin{array}{l}\text { Plural form of nouns } \\
\text { ending in ' } \mathrm{f} \text { ' or ' } \mathrm{fe} \text { ', }\end{array}$ & 46.50 & Average Mastery & 84.50 & Highly Mastered \\
\hline 7 & Words ending in 'ful' & 48.50 & Average Mastery & 81.50 & Highly Mastered \\
\hline 8 & $\begin{array}{l}\text { Words that need to be } \\
\text { added with 'ly' }\end{array}$ & 39.50 & Low Mastery & 80.50 & Highly Mastered \\
\hline 9 & $\begin{array}{l}\text { Words ending in } 1 \text { and be } \\
\text { added with 'all' or 'till' }\end{array}$ & 45.50 & Average Mastery & 83.00 & Highly Mastered \\
\hline 10 & $\begin{array}{l}\text { Words with American and } \\
\text { British spelling }\end{array}$ & 45.50 & Average Mastery & 80.50 & Mastered \\
\hline 11 & Words ending in 'le' & 43.00 & Average Mastery & 81.50 & Highly Mastered \\
\hline 12 & $\begin{array}{l}\text { Words ending in ' } \mathrm{k} \text { ', 'ke', } \\
\text { 'ck' and 'ic' }\end{array}$ & 37.50 & Low Mastery & 80.00 & Mastered \\
\hline 13 & $\begin{array}{l}\text { Plural form of words } \\
\text { ending in ' } y \text { ' }\end{array}$ & 50.00 & Average Mastery & 82.00 & Highly Mastered \\
\hline 14 & $\begin{array}{l}\text { Words with letter } \\
\text { combination of 'ei' and }\end{array}$ & 38.50 & Low Mastery & 82.50 & Highly Mastered \\
\hline
\end{tabular}




\begin{tabular}{|c|l|c|c|c|c|}
\hline & 'ie' & & & & \\
\hline 15 & Words with silent letters & 38 & Low Mastery & 77.50 & Mastered \\
\hline & Overall Mean & $\mathbf{4 6 . 5 3}$ & $\begin{array}{l}\text { Average } \\
\text { Mastery }\end{array}$ & $\mathbf{8 1 . 8 0}$ & Mastered \\
\hline \hline
\end{tabular}

Presented in Table 2 is the performance of students in spelling from the Experimental Group. The pre-test result shows that the lowest mean of 37.50 percent correct responses is the competency on, "Words ending in ' $\mathrm{k}$ ', 'ke', 'ck' and 'ic"' and is described as "Low Mastery," while competency on "Words with silent "e"" got 67.50 percent correct responses.

Post-test result on the performance of students in spelling from the Experimental Group shows that competency on "Words with silent letters" got the lowest mean which is 77.50 percent, however, still it's described as "Mastered." The highest mean of correct responses of all the competencies is "Words with silent " $\mathrm{e}$ " which is 86.50 percent and is described as "Highly Mastered."

It can be gleaned from the results that mean percentage of correct responses of students in spelling using the Rule-based Spelling Worktext showed a significant increased from pre-test to post-test. The overall mean of 46.53 in pre-test which is described as "Average Mastery" became 81.80 in the post test and it is described as "Highly Mastered."

In support to this study, Tomlin (2005) stressed the letting the students overcome their spelling difficulties is teaching them the rule-based spelling strategy. He also believed that rule-based strategy in spelling to be employed in the classroom can enhance students' performance in spelling. In addition, Johnson (2013) stated that increased in spelling knowledge also was associated with word recognition skills.

\section{Evaluation Rating of the Rule-based Spelling Worktext}

Table 3. Evaluation Rating of the Rule-based Spelling Worktext as to its Content

\begin{tabular}{|c|c|c|c|}
\hline \multicolumn{2}{|r|}{ Indicators } & \multirow{2}{*}{$\begin{array}{c}\text { Mean } \\
4.80\end{array}$} & \multirow{2}{*}{$\begin{array}{c}\text { Description } \\
\text { Excellent }\end{array}$} \\
\hline 1 & $\begin{array}{l}\text { The Module aligns with } \mathrm{K}-12 \\
\text { Curriculums goals. }\end{array}$ & & \\
\hline 2 & $\begin{array}{l}\text { The learning objectives are clearly } \\
\text { defined and stated. }\end{array}$ & 4.90 & Excellent \\
\hline 3 & $\begin{array}{l}\text { The sequence of activities is } \\
\text { appropriate to the learners. }\end{array}$ & 5.00 & Excellent \\
\hline 4 & $\begin{array}{l}\text { The directions are specific and } \\
\text { understandable. }\end{array}$ & 5.00 & Excellent \\
\hline 5 & $\begin{array}{l}\text { The exercises are sufficient for practice } \\
\text { sessions. }\end{array}$ & 4.80 & Excellent \\
\hline 6 & $\begin{array}{l}\text { The Module follows good English } \\
\text { language usage. }\end{array}$ & 5.00 & Excellent \\
\hline 7 & $\begin{array}{l}\text { The module contains right assessment } \\
\text { tools for the learners. }\end{array}$ & 4.80 & Excellent \\
\hline 8 & $\begin{array}{l}\text { The lessons are realistic and in logical } \\
\text { order. }\end{array}$ & 4.70 & Excellent \\
\hline 9 & $\begin{array}{l}\text { The Module allows are individualized } \\
\text { and experiential learning. }\end{array}$ & 4.80 & Excellent \\
\hline 10 & $\begin{array}{l}\text { The content provides a drive for further } \\
\text { enhancement. }\end{array}$ & 5.00 & Excellent \\
\hline & Mean & 4.88 & Excellent \\
\hline
\end{tabular}


The table 3 reveals the evaluation rating of the Rule-based Spelling Worktext as to its content. As shown, the indicator "The lessons are realistic and in logical order" got the lowest mean of 4.70 and is described as "Excellent", while the indicator "The sequence of activities is appropriate to the learners," "The directions are specific and understandable," "The Module follows good English language usage", and "The content provides a drive for further enhancement" got the highest mean of 5.00 and are all described as "Excellent." The mean is 4.88 and is described as "Excellent".

It can be gleaned from the results that the level of acceptability of the content of the Rule-based Reading Worktext is "Excellent". This study suggests that modules and other learning materials used in the $21^{\text {st }}$ century classroom should be relevant in its content and congruent with the competencies set by the DepEd.

Table 4. Evaluation Rating of the Rule-based Spelling Worktext as to its Relevance

\begin{tabular}{|c|c|c|c|}
\hline \multicolumn{2}{|r|}{ Indicators } & \multirow{2}{*}{$\begin{array}{c}\text { Mean } \\
4.70 \\
4.90\end{array}$} & \multirow{2}{*}{$\begin{array}{c}\text { Description } \\
\text { Excellent }\end{array}$} \\
\hline 1 & $\begin{array}{l}\text { The module's provide activities are } \\
\text { appropriate and relevant to student's } \\
\text { needs. }\end{array}$ & & \\
\hline 2 & $\begin{array}{l}\text { The content provides an impetus for } \\
\text { further research. }\end{array}$ & & \\
\hline 3 & $\begin{array}{l}\text { The module provides evidences of } \\
\text { effectiveness through pre-test and post- } \\
\text { test result. }\end{array}$ & 5.00 & Excellent \\
\hline 4 & $\begin{array}{l}\text { The learning tasks are related to the } \\
\text { expected content and skill to be } \\
\text { developed among the grade } 11 \text { student }\end{array}$ & 4.60 & Excellent \\
\hline 5 & $\begin{array}{l}\text { The module meets the minimum } \\
\text { requirements set for the Grade } 11 \\
\text { English subject. }\end{array}$ & 4.70 & Excellent \\
\hline 6 & $\begin{array}{l}\text { The module instruction materials are } \\
\text { suitable for individual use. }\end{array}$ & 4.90 & Excellent \\
\hline 7 & $\begin{array}{l}\text { The module gives the teacher, tutors and } \\
\text { grade } 11 \text { student an opportunity for the } \\
\text { desired achievement. }\end{array}$ & 4.70 & Excellent \\
\hline 8 & $\begin{array}{l}\text { The module topics are attuned to the } \\
\text { interest and urgent needs. }\end{array}$ & 4.80 & Excellent \\
\hline 9 & $\begin{array}{l}\text { The module could develop critical } \\
\text { thinking skills and mastery of reading } \\
\text { concepts. }\end{array}$ & 4.70 & Excellent \\
\hline 10 & $\begin{array}{l}\text { The module package is appropriate for } \\
\text { teaching spelling. }\end{array}$ & 5.00 & Excellent \\
\hline & Mean & 4.82 & Excellent \\
\hline
\end{tabular}

Table 4 presents the result of evaluation rating of the Rule-based Spelling Worktext as to its relevance. As shown here, the indicator on "The learning tasks are related to the expected content and skill to be developed among the Grade 11 students" got the lowest mean of 4.60 and is described as "Excellent" while the indicators "The module provides evidences of effectiveness through pre-test and post-test result "and "The module package is appropriate for teaching spelling" got the highest mean of 5.00 and is described as "Excellent."

The mean of 4.82 is described as "Excellent." It means that the level of acceptability of the relevance of the module to Grade 11 learning is excellent. 
The module should be relevant to the learners' level of competence especially for the TVL students who are not linguistically inclined.

Table 5. Evaluation Rating of the Rule-based Spelling Worktext as to its Instructional Aspect

\begin{tabular}{|c|c|c|c|}
\hline \multicolumn{2}{|r|}{ Indicators } & \multirow{2}{*}{$\frac{\text { Mean }}{4.90}$} & \multirow{2}{*}{$\begin{array}{c}\text { Description } \\
\text { Excellent }\end{array}$} \\
\hline 1 & $\begin{array}{l}\text { The module include contains easily } \\
\text { understandable direction for users. }\end{array}$ & & \\
\hline 2 & $\begin{array}{l}\text { The module includes non-threatening, } \\
\text { positive feedback. }\end{array}$ & 4.70 & Excellent \\
\hline 3 & $\begin{array}{l}\text { The module contains variety of exercise } \\
\text { for active learning. }\end{array}$ & 4.50 & Excellent \\
\hline 4 & $\begin{array}{l}\text { The module is interactive and easy to } \\
\text { navigate. }\end{array}$ & 4.70 & Excellent \\
\hline 5 & The program techniques are appropriate. & 4.80 & Excellent \\
\hline 6 & $\begin{array}{l}\text { The module stimulates promising } \\
\text { readers interest and curiosity. }\end{array}$ & 4.60 & Excellent \\
\hline 7 & $\begin{array}{l}\text { The module shows strong relevance to } \\
\text { Grade } 11 \text { students' experiences. }\end{array}$ & 4.70 & Excellent \\
\hline 8 & $\begin{array}{l}\text { The program shows evidences of } \\
\text { effectiveness. }\end{array}$ & 4.80 & Excellent \\
\hline 9 & $\begin{array}{l}\text { The module facilitates easy integration } \\
\text { into the program. }\end{array}$ & 4.70 & Excellent \\
\hline 10 & $\begin{array}{l}\text { The spelling concepts are in simplified } \\
\text { form. }\end{array}$ & 5.00 & Excellent \\
\hline & Mean & 4.74 & Excellent \\
\hline
\end{tabular}

As gleaned in Table 5, the evaluation rating of the Rule-based Spelling Worktext as to its instructional aspect showed as "Excellent" as shown by its mean which is 4.74. It is also shown that the indicator "The module contains variety of exercise for active learning" which got a lowest mean of 4.50, while the indicator "The spelling concepts are in simplified form" got the highest mean of 5.00 and is described as "Excellent." The mean of 4.74 showed that the acceptability of the Reading Worktext as to its Instructional Aspect is described as "Excellent."

This study is supported by Sumido (2016) when she stated that instructional Materials are the tools used in educational lessons, which includes active learning and assessment. Basically, any resource a teacher uses to help him teach his students is an instructional material. Instructional materials are the content or information conveyed within a course. Sumido (2016) also added that the instructional materials must be carefully planned, selected, organized, refined, and used in a course for the maximum effect. The planning and selection of instructional materials should take into consideration both the breadth and depth of content so that student learning is optimized.

Table 6. Summary of Acceptability of the Rule-based Spelling Worktext

\begin{tabular}{|l|l|c|c|}
\hline \hline \multicolumn{2}{|c|}{ Indicators } & Mean & Description \\
\hline 1 & Content & 4.88 & Excellent \\
\hline 2 & Relevance & 4.82 & Excellent \\
\hline 3 & Instructional Aspect & 4.74 & Excellent \\
\hline \multicolumn{2}{|c|}{ Overall Mean } & $\mathbf{4 . 8 1}$ & Excellent \\
\hline \hline
\end{tabular}

As shown in Table 6, the indicators on the level of acceptability of the Rule-based Spelling Worktext got an overall mean of 4.81 and is described as "Excellent." It can be 
interpreted that the Rule-based Spelling Worktext is excellent and is highly acceptable for students in learning spelling.

Sumido (2016) stated that the best instructional materials are those that include includes active learning and assessment. She added that any source a teacher employs in teachinglearning activity is an instructional material. She emphasized that the instructional materials must be carefully planned, selected, organized, refined, and used in a course for the maximum effect. The planning and selection of instructional materials should take into consideration both the breadth and depth of content so that student learning is optimized.

Rules are a favorite teaching tool as they provide some guidance and structure to lessons. Nonetheless, they are important for students to learn the exceptions to them too (https://www.readandspell.com/us/developing-spelling-skills).

Table 7. Analysis on the Spelling Performance of Grade 11-TVL Students Between Control Group and Experimental Group in the Pre-test

\begin{tabular}{|l|l|c|c|c|c|c|}
\hline \hline \multicolumn{2}{|c|}{ Groups } & N & Mean & sd & $\mathbf{z}_{\text {comp }}$ value & $\mathbf{z}_{\text {crital }}$ value \\
\hline 1 & Control Group & 50 & 22.30 & 3.22 & $1.667^{\text {ns }}$ & 1.960 \\
\hline 2 & Experimental Group & 50 & 23.80 & 3.25 & & \\
\hline \hline
\end{tabular}

ns - not significant at 0.05 level

As presented in Table 7, the spelling ability of the control and experimental groups was not significantly different as indicated by the $\mathrm{z}_{\text {comp }}$ value of 1.667 which is less than the $Z_{\text {critical }}$ value of 1.960 . The result implies that the spelling performance of the students in control group and experimental group was comparable. The standard deviation of the control group is 3.22 while the experimental group is 3.35. Since the standard deviation is low, it means that the raw scores of the students were closely related to each other in the pre-test.

Table 8. Spelling Performance of Grade 11-TVL Students in the Control Group in Pre-test and Post-test

\begin{tabular}{|c|l|c|c|c|c|c|}
\hline \hline \multicolumn{2}{|c|}{ Types of Test } & $\mathbf{N}$ & Mean & sd & $\mathbf{z}_{\text {comp }}$ value & $\mathbf{z}_{\text {crital }}$ value \\
\hline 1 & Pre-test & 50 & 22.30 & 3.22 & $10.944 *$ & 1.960 \\
\hline 2 & Post-test & 50 & 30.26 & 4.00 & & \\
\hline
\end{tabular}
* significant at 0.05 level

The spelling ability of the control group in the pre-test and post-test was significantly different as indicated by the $\mathrm{z}_{\text {comp }}$ value of 10.944 which is greater than $\mathrm{z}_{\text {critical }}$ value of 1.960. These results further showed that the spelling performance of the students in the control group was significantly higher after their exposure to the Copy-Only Method. The standard deviation of the pre-test is 3.22 while in the post test is 4.00 of the control group. This means that there are students who really showed significant increase in their post-test scores that made the individual scores more scattered compared to the pre-test.

Johnson (2013) explained that the Copy-Only Method in teaching spelling can be one of the strategies to help students improve their competence in spelling, however, the gain and progress can only be minimal compared to the gain and progress they get using the RuleBased instruction in spelling.

Table 9. Spelling Performance of Grade 11-TVL Students in the Experimental Group in Pre-test and Post-test

\begin{tabular}{|l|l|c|c|c|c|c|}
\hline \hline \multicolumn{2}{|c|}{ Types of Test } & $\mathbf{N}$ & Mean & sd & $\mathbf{z}_{\text {comp }}$ value & $\mathbf{z}_{\text {crital }}$ value \\
\hline 1 & Pre-test & 50 & 23.38 & 3.22 & $24.249^{*}$ & 1.960 \\
\hline 2 & Post-test & 50 & 41.10 & 4.00 & & \\
\hline
\end{tabular}


As shown, the spelling ability of the experimental group in the pre-test and post-test was significantly different as indicated by the $\mathrm{Z}_{\text {comp }}$ value of 24.249 which is greater than the $Z_{\text {critical }}$ value of 1.960. The standard deviation of the experimental group in pre-test is 3.22 while in the post test is 2.98 . It can also be gleaned from the data presented that the spelling performance of students from the experimental group was not comparable. Their spelling performance after the experimentation was significantly higher compared to their spelling performance as indicated by the pre-test. This signifies that there is an improvement of the spelling performance of the students from pre-test to post test.

Table 10. Spelling Performance of Grade 11-TVL Students in the Control Group and Experimental Group in Post-test

\begin{tabular}{|l|l|c|c|c|c|c|}
\hline \hline \multicolumn{2}{|c|}{ Types of Test } & $\mathbf{N}$ & Mean & sd & $\mathbf{z}_{\text {comp value }}$ & $\mathbf{z}_{\text {crital }}$ value \\
\hline 1 & Pre-test & 50 & 30.26 & 4.00 & $13.516^{*}$ & 1.960 \\
\hline 2 & Post-test & 50 & 41.10 & 2.98 & & \\
\hline
\end{tabular}

As gleaned in Table 10, the spelling ability of the control and experimental groups was significantly different as indicated by the $\mathrm{Z}_{\text {comp }}$ value of 13.516 is greater than the $\mathrm{Z}_{\text {critical }}$ value of 1.960. The standard deviation of the control group during post-test is 4.00 while the standard deviation of the experimental group in the pos test is 2.98 . This means that the spelling performance of students from the control group and experimental groups was significantly different in favor of the experimental group. Spelling of students in experimental group in the post-test was very closed to each other as indicated by the standard deviation of 2.98 .

This study is related to the study of Abbott (2001) who found that students engaged in word study spelling instruction outperformed their peers engaged in traditional spelling groups in overall orthographic development. Also, as children become confident in their ability to spell and identify patterns in words, they will be more likely to write freely and acquire foundational reading skills, such as word attack and word recognition (Graham et .al, 2008).

Table 11. Difference in the Mean Gain Scores of the Control Group and Experimental Group in the Post-test

\begin{tabular}{|c|c|c|c|c|c|c|}
\hline \multicolumn{2}{|c|}{ Types of Test } & $\mathbf{N}$ & Mean & sd & $\mathbf{z}_{\text {compvalue }}$ & $\mathbf{z}_{\text {crital }}$ value \\
\hline 1 & Pre-test & 50 & 7.96 & 4.31 & $11.367 *$ & 1.960 \\
\hline 2 & Post-test & 50 & 17.82 & 4.27 & & \\
\hline
\end{tabular}

It is presented in Table 8, the mean gain score of the control and experimental groups were significantly different as indicated by the $\mathrm{z}_{\text {comp }}$ value of 11.367 which is greater than $Z_{\text {critical }}$ value of 1.960 . The standard deviation of the control group in the mean gain score is 4.31while in the experimental group is 4.27. As shown in the table that it is very evident that the control group who used the Copy Only Method which is the traditional way has minimal learning in spelling while in the experimental group, students learned greater with the use of the Rule-Based Spelling Worktext as an effective instructional material. The K12 principles was integrated in the worktext wherein the students had the differentiated activities, contextualized/localized. 
These findings further implied that the experimental group performed better in post test than the control group. It further means that the use of the Rule-Based Spelling Worktext is effective.

\section{CONCLUSION}

Students in both control and experimental groups had an average mastery in spelling performance before the start of experimentation. After the exposure of control group to the Copy-Only Method and experimental group to the Rule-based Spelling Worktext, students in both groups achieved a mastery level in spelling. However, students' spelling performance in experimental was significantly higher compared to the spelling performance of students in control group. This significant increase of students' spelling performance in favor of experimental group was due to the Rule-based Spelling Worktext. The Rule-based Spelling Worktext is excellently acceptable instructional material in improving the performance of students in spelling.

The mean gain scores between the control group and the experimental group in post-test showed a valid evidence that students really learned from the Rule-based Spelling Worktext. This implied that the Rule-based Spelling Worktext is very effective in teaching spelling.

\section{Recommendations}

Having found that the Rule-based Spelling Worktext was effective in helping the students improve their performance in spelling, the following recommendations were formulated;

1. Use the Rule-based Spelling Worktext as an instructional material to help the students improve their performance in spelling.

2. Competencies in spelling should be given value in designing instructional plans inside the classroom.

3. If Department of Education (DepEd) wants to ensure better performance and quality learning outcomes in language, spelling instruction should be regularly integrated in the classroom teaching-learning process.

4. Strengthen Spelling Bee's in the school, division, region and even national level to challenge the teachers and students to be highly competent in spelling; and

5. Further research should focus on the other aspects of spelling instruction.

\section{REFERENCES}

Abbott, M. (2001). Effects of Traditional Versus Extended Word-Study Spelling Instruction on Students' Orthographic Knowledge. Reading Online. Retrieved from the Net: http://www.readingonline.org./articles/art-index.asp.HREI=abbott/index.html. Retrieved December 12, 2018

Barbe, W. \& Francis, A. (1994). Spelling Basic Skills for Effective Communication. Zaner NJ; Merril

Beer, D. Invernizzi, Mn Templeton, S. (2000). Words their Way: Word Study or Phonics, Vocabulary and Spelling Instruction. Upper Saddle River

Darch, C., \& Kim, S., Johnson, S., \& James, H. (2000). Journal of Instructional Psychology: The Strategic Spelling Skills of Students with Learning Disabilities. (2000). Retrieved from the net 4/12/2018. from http://www.findarticles.com/p/articles/mi_m0FCG/is_1_27/ai_629807424/pg_1

Flower, L., \& Hayes, J.R. (2011). A cognitive process theory of writing. Composition and Communication Retrieved from net 
https://etd.library.vanderbilt.edu/available/etd-07262013-132544/unrestricted/Thesis.pdf on September 11, 2018

Gagen, Miscese (2013). The Tools to Achieve Reading Success Very Good Retrieved from http://www.righttrackreading.com/howtospell.html on September 21, 2018

Graham, S., Harris, K. \& Chorzempa, B. (2004). Extra Spelling Instruction Promotes Better Spelling, Writing and Reading Performance right from the Start. CASL News: Promoting Success in Grades K-3, 9, 1-4. Retrieved from the net: http://scira.org/content/wp-content/uploads/2014-making-spelling-meaningfull.pdf. Retrieved August 11, 2018

Hall, Ana H. (2014). Making Spelling Meaningful: Using Explicit Instruction and Individual Conferencing. Retrieved from http://scira.org/content/wpcontent/uploads/2014-making-spelling-meaningfull.pdf. Retrieved August 11, 2018

Johnson, Mandi M. (2013) The Relationship Between Spelling Ability and Reading Fluency and Comprehension in Elementary Students. Master's Thesis Presented to Northern Michigan University. Retrieved from https://www.nmu.edu/education/sites/DrupalEducation/files/UserFiles/Johnson_Mandi_ MP.pdf Retrieved January 18, 2019

Jones S. (2018). Learning Disabilities OnLine: Five Guidelines for Learning to Spell and Six Ways to Practice Spelling. Retrieved from the net on 4/15/2018, from http://www.Idonline.org/ld_indepth/teaching_techniques/spelling_studying.html

Kamhi, A. G. \& Hinton, L. N. (2000). Explaining Individual Differences in Spelling Ability. Topics in Language Disorders Retrieved from the net https://www.mheducation.com.au/media/wysiwyg/AUS/Schools/Placementtests-

SS/SpellingMastery_PlacementTest.pdf Retrieved August 12, 2018

Knapp, Julie Shepherd (2006). The Home School Diner's Guide to Workbook and Worktext

Leipzig, D. H. (2000). Actions teach louder with words: How and what experienced teachers learn about embedded word study from classroom practice and an inquiry group. (Unpublished doctoral dissertation.) University of Maryland, College Park, MD. Retrieved from the Net: http://www.readingrockets.org /article/word- study-learningword-patterns Retrieved September 21, 2018

Orstein, Allan C. (1992). Strategies for effective Teaching, Philippines' copyright 1992 by HarperCollins publisher, Inc.

Porter, Michael C. (2003). Spelling Attitudes and Abilities of Secondary Students. Theses and Dissertation. 1358. Retrieved from the Net: http://rdw.rowan.edu/etd/1358. on August 12, 2018

Sumido, Analiza G. (2015). Bridging Culture for Reading at Home and School: It's Effect to Reading Fluency of the students, Regional BERF Research.

Warren, Erica (2013). Reading and Spelling Difficulties. Retrieved from https://learningspecialistmaterials.blogspot.com/2013/05/reading-and-spellingdifficulties-7.html on September 23, 2018

Tomlin, Matt (2018). Rule-based Spelling Strategy. Retrieved from ecialeducationawareness. blogspot. com/2005/05/rule-based-spelling-strategies.html on September 21, 2018 